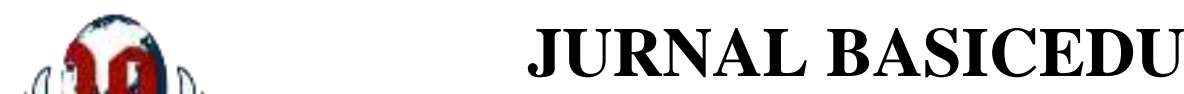

Volume 5 Nomor 6 Tahun 2021 Halaman 6103 - 6109

Research \& Learning in Elementary Education

https://jbasic.org/index.php/basicedu

\title{
Validitas E-Modul Matematika Sekolah Dasar Berbasis Pendekatan Realistic Mathematics Education (RME)
}

\author{
Nur Atikah $^{1 凶}{ }^{\bowtie}$ Nurhizrah Gistituati $^{2}$, Hendra Syarifuddin ${ }^{3}$, Yanti Fitria ${ }^{4}$ \\ Universitas Negeri Padang, Indonesia ${ }^{1,2,3,4}$ \\ E-mail: nurnuratikah7@gmail.com ${ }^{1}$, gistituatinurhizrah@gmail.com ${ }^{2}$, hendras@ fmipa.unp.ac.id $^{3}$, \\ yanti_fitria@fip.unp.ac.id ${ }^{4}$
}

\begin{abstract}
Abstrak
Perkembangan teknologi menuntut pendidik untuk melakukan inovasi dalam pembelajaran salah satunya dengan mengembangkan bahan ajar dalam bentuk elektornik atau biasa disebut e-modul. E-modul matematika bersifat dinamis, memotivasi serta mengajak siswa belajar mandiri. Tujuan dari penelitian ini untuk mengungkap tingkat kevalidan e-modul matematika SD berbasis pendekatan RME yang dikembangkan. Jenis penelitian yang digunakan yaitu R\&D dengan model SD (define, design, develop, and desiminate). lembar validitas merupakan insrumen yang digunakan dalam penelitian ini. Peneliti melakukan analisis lembar validasi dengan skala likert untuk mengetahui kualitas dari e-modul yang dikembangkan. Hasil validasi ahli materi mendapat nilai 93,8\% dengan kategori sangat valid. Begitu juga dengan hasil validasi ahli desain dan bahasa mendapat nilai sebesar 93\% dengan kategori sangat valid. Sehingga e-modul matematika SD berbasis pendekatan RME valid dan sangat layak untuk digunakan sebagai bahan ajar matematika khususnya materi pecahan karena memenuhi kriteria penelaian.
\end{abstract}

Kata Kunci: e-modul, pendekatan RME, matematika, SD, validitas

\section{Abstract}

Technological developments require educators to innovate in learning, one of which is by developing teaching materials in electronic form or commonly called e-modules. Mathematics e-module is dynamic, motivating, and invites students to learn independently. The purpose of this study is to reveal the level of validity of the e-module of elementary mathematics based on the RME approach that was developed. The type of research used is $R \& D$ with the SD model (define, design, develop, and disseminate). The validity sheet is the instrument used in this study. The researcher analyzed the validation sheet with a Likert scale to determine the quality of the developed e-module. The results of material expert validation got a score of $93.8 \%$ with a very valid category. Likewise, the results of the validation of design and language experts got a score of $93 \%$ with a very valid category. So that the elementary mathematics e-module based on the RME approach is valid and very feasible to be used as mathematics teaching materials, especially fractions because it meets the assessment criteria.

Keywords: e-module, RME approach, mathematics, elementary school, validity

Copyright (c) 2021 Nur Atikah, Nurhizrah Gistituati, Hendra Syarifuddin, Yanti Fitria

$\triangle$ Corresponding author :

Email : nurnuratikah7@gmail.com

DOI : https://doi.org/10.31004/basicedu.v5i6.1799

ISSN 2580-3735 (Media Cetak)

ISSN 2580-1147 (Media Online) 
6104 Validitas E-Modul Matematika Sekolah Dasar Berbasis Pendekatan Realistic Mathematics Education (RME) - Nur Atikah, Nurhizrah Gistituati, Hendra Syarifuddin, Yanti Fitria

DOI: https://doi.org/10.31004/basicedu.v5i6.1799

\section{PENDAHULUAN}

Matematika perlu dikuasai oleh setiap siswa untuk masa depan, termasuk siswa sekolah dasar. Banyak hasil penelitian yang membuktikan bahwa pembelajaran matematika bisa meningkatkan kemampuan siswa berpikir kreatif, logis, juga mengembangkan keterampilan ketika memecahkan permasalahan (Widyatiningtyas et al., 2015);(Samo, 2017). Kemampuan-kemampuan tersebut sangat diperlukan dalam kehidupannya seharihari (Ediyanti et al., 2020);(Tanujaya et al., 2017);(Lachner \& Nückles, 2016), serta berguna dalam menghadapi kemajuan teknologi(Ardiyani, 2018);(Yanti Fitria et al., 2019). Maka dari itu matematika sangat penting untuk dipelajari di setiap jenjang persekolahan, terutama sekali di sekolah dasar. Keberhasilan mereka ketika belajar di SD akan memungkinkan mereka untuk juga berhasil ketika belajar matematika pada jenjang pendidikan selanjutnya.

Namun, dari hasil penelitian ditemukan bahwa masih banyak siswa di setiap jenjang pendidikan yang kurang menyukai pembelajaran matematika (Mentari \& Syarifuddin, 2020);(Y. Fitria et al., 2019), dan juga kurang memiliki pemahaman matematis (Fernandes \& Syarifudin, 2019). PISA tahun 2018 memperlihatkan bahwa Indonesia selalu di peringkat 6 terbawah dalam bidang matematika (Atikah et al., 2020). Hal ini didukung oleh penelitian Sari yang menjelaskan bahwa mata pelajaran yang paling sulit dipelajari yaitu matematika (Sari et al., 2019). Kesulitan siswa dalam menggunakan simbol matematika menyebabkan mereka mengalami kesalahan ketika menggunakan konsep untuk menyelesaikan masalah (Kurani \& Syarifuddin, 2020);(Syarifuddin, 2018). Permasalahan di atas tidak bisa dibiarkan dan harus dicarikan penyelesaiannya agar kemampuan matematis siswa meningkat. Salah satu penyebab kekurangsukaan dan kekurangmampuan siswa dalam pembelajaran matematika adalah pendidik memanfaatkan bahan ajar yang membuat siswa kurang tertarik (Syaspasbandah et al., 2018), dan belum berorientasi pada kehidupan nyata (Fajri et al., 2020).

Kenyataanya di lapangan ditemukan bahwa, belum ada pengembangan bahan ajar matematika yang dikembangkan guru. Padahal pada buku paket yang digunakan belum memanfaatkan lingkungan kehidupan siswa sebagai stimulus yang memotivasi siswa untuk memahami materi matematika. Siswa yang selalu dituntut untuk mencatat materi atau rumus yang ada di buku membuat proses pembelajaran menjadi membosankan. Guru yang masih mendominasi membuat pembelajaran belum berpusat kepada siswa, serta siswa belum terpancing untuk mengkomunikasikan ide matematika yang dimilikinya membuat pembelajaran tidak interaktif.

Guru belum memberikan permasalahan yang dekat dengan siswa supaya siswa mau menjawab pertanyaan yang guru ajukan. Jika guru hanya menggunakan soal yang terdapat di buku paket dan selalu menuntut siswa menjawab dengan benar tanpa ingin mengetahui dari mana siswa mendapatkan jawaban tersebut akan merubah persepsi siswa bahwa untuk matematika nilainya harus selalu bagus baimana pun caranya. Anggapan ini akan membuat siswa tidak memiliki sikap menghargai matematika dalam kehidupan sehari-harinya.

Saat ini hampir semua jenjang Pendidikan melaksanakan pembelajaran online. Pembelajaran online menuntut siswa untuk belajar secara mandiri. Selama proses pembelajaran siswa memperhatikan komputer atau gawai bahkan untuk mengerjakan evaluasi siswa juga harus memanfaat teknologi(Yumiarti, 2020);(Sahidin et al., 2021). Selama pembelajaran online dilaksanakan semua kegiatan diskusi harus menuntaskan tujuan pembelajaran yang telah dibuat. Siswa yang mampu mengkonstruksikan pengetahuannya sendiri dapat dikatakan bahwa siswa telah belajar dengan baik dan aktif.

E-modul matematika membantu siswa saat pembelajaran online. Materi yang diterima siswa diharapkan bisa disimpan ke dalam memori karena siswa tidak menghafal melainkan menyimpulkan sendiri apa yang sudah mereka pelajari. Dengan begitu e-modul matematika membantu siswa dalam pembelajaran online sehingga siswa bisa belajar mandiri dan materi yang dikuasai bisa menyelesaikan kehidupan nyata atau riil karena siswa telah memiliki berbagai alternatif cara menyelesaikan masalah di dalam memorinya.

Selama ini sudah banyak peneliti yang mengembangkan modul matematika. Salah satunya yaitu modul matematika yang mengintegrasikan nilai keislaman dengan menerapkan RME di SMP (Yuniati et al., 2018); 
(Lasmiyati \& Harta, 2014). Peneliti lain melakukan pengembangan e-modul dengan pendekatan saintifik berbasis software Kvisoft Flipbook Maker Pro untuk SMA (Fonda, 2018);(Ilmi et al., 2021). Namun karena modul yang sudah dikembangkan hanya untuk siswa SMP dan SMA dengan begitu penulis ingin mengembangkan e-modul matematika berbasis pendekatan RME untuk siswa SD.

Maka dari itu tujuan penelitian ini adalah mengembangan e-modul berbasis pendekatan matematika realistik (RME) yang valid. Bahan ajar dalam bentuk e-modul dipilih karena bersifat dinamis, dapat menumbuhkan motivasi belajar, dan membuat siswa lebih mandiri selama pembelajaran online. Lebih lanjut, emodul ini dibuat untuk pembelajaran online maupun offline agar dapat ditemukan dengan mudah oleh siswa maupun guru melalui jaringan internet untuk menunjang pembelajaran matematikanya.

\section{METODE}

Penulis menggunakan penelitian dan pengembangan dengan model 4D. Pada tahap define peneliti melakukan analisis kurikulum, analisis kebutuhan, dan analisis peserta didik. Pada tahap design, peneliti melakukan merancang instrument dan merancang e-modul matematika SD berbasis pendekatan RME. Pada tahap develop, peneliti mengembangkan RPP dan e-modul setelah itu dilakukan uji validitas dan uji praktikalitas. Tahap terakir yaitu desiminate, peneliti melakukan uji efektivitas dan penyebaran e-modul matematika berbasis pendekatan RME pada sekolah lain. Sampel dari penelitian yaitu siswa kelas IV dan para ahli. 5 ahli yang memvalidasi e-modul yaitu 3 orang ahli materi matematika dan 2 orang yang ahli desain dan bahasa. Lembar validasi merupakan instrumen dan teknik pengumpulan data yang penulis gunakan. Teknik analisis data yaitu analisis kevalidan dengan mencari rata-rata skor lalu diinterpretasikan pada kategori kevalidan.

$$
\bar{X}=\frac{\sum X_{i}}{n}
$$

Keterangan:

$\overline{\mathrm{X}} \quad=$ Rata-rata skor validasi

$\sum \mathrm{X}_{\mathrm{i}} \quad=$ Jumlah skor dari hasil validasi

$\mathrm{n} \quad=$ Jumlah aspek yang dinilai

Setelah skor persentase uji validitas oleh tenaga ahli didapatkan dengan menggunakan rumus di atas selanjutnya hasil presentasi tersebut dikategorikan berdasarkan tabel ketetapan validas di bawah ini.

Tabel 1

Kriteria Interpretasi Skor Uji Validitas

\begin{tabular}{|c|c|c|}
\hline No. & Rerata Skor & Kategori \\
\hline 1 & $\mathrm{X}>4,20$ & Sangat Valid \\
\hline 2 & $3,40<\mathrm{X} \leq 4,20$ & Valid \\
\hline 3 & $2,60<\mathrm{X} \leq 3,40$ & Cukup Valid \\
\hline 4 & $1,80<\mathrm{X} \leq 2,60$ & Kurang Valid \\
\hline 5 & $\mathrm{X} \leq 1,80$ & Tidak Valid \\
\hline
\end{tabular}

\section{HASIL DAN PEMBAHASAN}

\section{Tahap Define}

\section{Analisis Kebutuhan}

Peneliti melakukan observasi di dua sekolah yaitu SD X di Kota Bengkulu dan SD Y di Kota Padang ditemukan bahwa pembelajaran yang dilakukan sudah menerapkan kurikulum 2013 sejak 2016. Namun, belum menggunakan bahan ajar tambahan yang menyajikan gambar atau permasalahan sehari-hari yang menstimulus siswa untuk interaktif dan kolaboratif selama proses pembelajaran berlangsung. 
6106 Validitas E-Modul Matematika Sekolah Dasar Berbasis Pendekatan Realistic Mathematics Education (RME) - Nur Atikah, Nurhizrah Gistituati, Hendra Syarifuddin, Yanti Fitria

DOI: https://doi.org/10.31004/basicedu.v5i6.1799

2. Analisis Kurikulum

Peneliti menganalisis KI, KD dan tujuan pembelajaran yang dikembangkan untuk mengetahui sejauh mana siswa kelas empat sudah mempelajari materi pecahan sehingga peneliti dapat mengembangkan tujuan pembelajaran tambahan yang harus dicapai siswa untuk memaksimalkan hasil belajar.

\section{Analisis Peserta Didik}

Siswa kelas 4 berada pada usia 10-11 tahun dengan tahap belajar operasional kontrik atau sudah belajar untuk mengorganisasikan suatu informasi namun dengan bantuan stimulus dari benda nyata.

\section{Tahap Design}

1. Menyusun Instrumen

Peneliti menyusun instrument berupa lembar validasi, lembar angket untuk uji praktikalitas dan tes uraian untuk melakukan uji efektivitas.

2. Mendesain E-modul

Peneliti mendesain mulai dari cover, KD, indikator dan tujuan belajar yang ingin dicapai. Petunjuk belajar, peta konsep, materi pecahan, soal latihan, rangkuman dan evaluasi pada Microsoft word 2019. Setelah itu hasil dari mw 2019 diinput ke dalam aplikasi flip pdf pro supaya bisa berbentuk buku seara online. Sehingga bisa diakses oleh siswa kapanpun dan dimanapun mereka berada.

\section{Develop}

\section{Mengembangkan RPP}

Peneliti mengembangkan 2 jenis RPP untuk kelas kontrol dan eksperimen, yang terdiri dari 5 kali pertemuan. 2 RPP digunakan saat uji coba dan 3 RPP digunakan saat proses pembelajaran menggunakan emodul matematika SD berbasis pendekatan RME.

2. Mengembangkan E-modul berbasis Pendekatan RME

E-modul matematika yang sudah dionlinekan dalam bentuk aplikasi Flip Prf Pro tadi divalidasi oleh pakar. Materi pecahan dinilai oleh 3 orang pakar yaitu 1 orang guru SD kelas IV dan 2 orang dosen matematika. Terdapat beberapa revisi yang disarankan oleh validator sebelum e-modul dinilai sudah valid dan bisa digunakan. Seperti pemilihan gambar, penyajian soal cerita, penyelesaian masalah, penyampaian konsep dan kesesuaian karakteristik RME dengan materi yang disampaikan. Setelah direvisi e-modul divalidasi pakar kembali sampai dikategorikan valid untuk dicobakan di lapangan. Hasil validasi e-modul matematika berbasis pendekatan RME pada aspek materi secara ringkas dirangkum pada Tabel 2.

Tabel 2

Hasil Validasi E-Modul Pada Aspek Materi

\begin{tabular}{clcc}
\hline No & \multicolumn{1}{c}{ Aspek } & $\begin{array}{c}\text { Rata-rata } \\
\text { Skor }\end{array}$ & Keterangan \\
\hline 1 & 4,52 & Sangat Valid \\
2 & $\begin{array}{l}\text { Belajar Mandiri (Self } \\
\text { Instruction) } \\
\text { Belajar Tuntas (Self }\end{array}$ & 4,78 & Sangat Valid \\
& $\begin{array}{l}\text { Contained) } \\
3\end{array}$ & 4,67 & Sangat Valid \\
& $\begin{array}{l}\text { Berdiri Sendiri (Standar } \\
\text { Alone) }\end{array}$ & 4,5 & Sangat Valid \\
4 & Adaptif & 4,89 & Sangat Valid \\
5 & Bersahabat (User Friendly) & 4,81 & Sangat Valid \\
6 & Komponen E-modul & 4,67 & Sangat Valid \\
7 & Pendekatan RME & 4,69 & Sangat Valid \\
Rata-rata total & & \\
\hline
\end{tabular}


Dari table 2 di atas, bisa dipahami bahwa skor yang diberi para pakar didapat skor rata-rata sebesar 4,69 atau dikategorikan sangat valid. Aspek belajar mandiri dengan skor rata-rata sebesar 4,52 diindikasikan sangat valid; aspek belajar tuntas dengan skor rata-rata sebesar 4,78 dikategorikan sangat valid; aspek berdiri sendiri dengan skor rata-rata sebesar 4,67 diindikasikan sangat valid; aspek adaptif disimpulkan sangat valid dengan skor rata-rata sebesar 4,5; aspek bersahabat dengan skor rata-rata sebesar 4,89 diindikasikan sangat valid; aspek komponen e-modul dikategorikan sangat valid dengan skor rata-rata sebesar 4,81; dan pada aspek validasi pendekatan RME disimpulkan sangat valid dengan skor rata-rata sebesar 4,67.

Untuk bahasa dan desain dari e-modul dinilai oleh dua orang dosen. Kedua dosen ini memberikan masukan dan saran mengenai desain dari e-modul serta penggunaan bahasa pada e-modul disederhanakan supaya bisa dipahami dengan mudah oleh siswa SD. Setelah direvisi e-modul pada aplikasi Flip Pdf Pro diberikan kembali kepada validator untuk dinilai apakah sudah pantas untuk diujicobakan atau masih perlu perbaikan setelah e-modul dikatakan layak untuk diuji cobakan maka validator memberikan nilai untuk mengetahui seberapa layak e-modul yang dikembangkan dengan menginterprestasikannya pada kategoti kevalidan. Hasil validasi e-modul matematika SD disajikan pada Tabel 3.

Tabel 3

Hasil Validasi E-Modul Aspek Kebahasaan dan Desain

\begin{tabular}{llcl}
\hline No & \multicolumn{1}{c}{ Aspek } & Rata-rata Skor & Keterangan \\
\hline 1 & Kualitas Grafis & 4,58 & Sangat Valid \\
2 & Kelayakan Bahasa & 4,6 & Sangat Valid \\
3 & Cover/Sampul E-modul & 4,79 & Sangat Valid \\
4 & Isi E-Modul & 4,43 & Sangat Valid \\
5 & Kelayakan E-modul & 4,83 & Sangat Valid \\
& Sebagai Bahan Ajar & & \\
Rata-rata total & 4,65 & Sangat Valid \\
\hline
\end{tabular}

Tabel 3 di atas menjelaskan bahwa hasil penilaian pakar ahli media didapat skor rata-rata 4,65 atau dikategorikan sangat layak. Pada aspek kualitas grafis skor rata-rata 4,58 dengan keterangan sangat valid; Pada kelayakan bahasa skor rata-rata 4,6 dengan kategori sangat valid; kelayakan cover/sampul skor rata-rata 4,79 dengan keterangan sangat valid; aspek kelayakan isi e-modul juga sangat valid dengan skor rata-rata 4,3, dan kelayakan e-modul sebagai bahan ajar sangat valid dengan skor rata-rata 4,83.

Hasil penilaian validator ahli menyimpulkan bahwa e-modul matematika yang telah dikembangkan dikatakan sangat valid ditinjau dari aspek materi (belajar mandiri, belajar tuntas, berdiri sendiri, adaptif, bersahabat, serta komponen e-modul) maupun aspek kebahasaan dan desain (aspek kualitas grafis, kelayakan bahasa, cover/sampul modul, isi modul, dan aspek kelayakan modul sebagai bahan ajar). Berdasarkan hasil penilaian dari validator maka e-modul sudah bisa untuk diuji cobakan di lapangan.

Temuan ini mendukung penelitian terdahulu (Apriansyah \& Pujiastuti, 2020) yang menjelaskan bahwa bahan ajar berbasis gnomio mendapat nilai dari ahli materi dan media sebesar 4,56 maka dari itu bahan ajar ini layak dipergunakan oleh siswa. Ditambahkan oleh (Oktaviara \& Pahlevi, 2019) menyimpulkan e-modul sangat baik digunakan dengan perolehan skor 90\% untuk kebahasaan dan kegrafikan 83,15\% dengan kriteria sangat valid. Elektronik modul yang valid harus memiliki KD, materi pokok dan pengembangan dari tujuan pembelajaran yang jelas supaya siswa lebih mudah memahaminya (Hendri et al., 2021). Modul elektronik atau modul digital yang baik harus bisa terbaca oleh siswa, komunikatif, serta sesuai dengan kaedah bahasa Indonesia. Elektronik modul juga memperhatikan kesesuaian layout cover, komposisi warna, sinkronisasi anatra grafis dan visual serta kesesuaian tata letak. Dipertegas oleh Permana bahwa desain layer harus diperhatikan ketika mengembangka modul elektronik (Febriyanti \& Ain, 2021). 
6108 Validitas E-Modul Matematika Sekolah Dasar Berbasis Pendekatan Realistic Mathematics Education (RME) - Nur Atikah, Nurhizrah Gistituati, Hendra Syarifuddin, Yanti Fitria

DOI: https://doi.org/10.31004/basicedu.v5i6.1799

\section{KESIMPULAN}

E-modul matematika berbasis pendekatan RME yang dikembangkan menggunakan model 4D. Tahap define peneliti melakukan analisis peserta didik, analisis kurikulum dan analisis kebutuhan. Pada tahap design, menyusun instrument dan menyusun e-modul. Pada tahap develop, peneliti mengembangkan RPP dan mengembangkan RPP, mengembangkan e-modul, uji validitas dan praktikalitas. Pada tahap desiminate, peneliti melakukan uji efektivitas dan penyebaran ke sekolah lain. Berdasarkan penyajian dari temuan penelitian, dapat ditarik kesimpulan bahwa e-modul berbasis pendekatan RME yang sudah dihasilkan mempunyai kategori kevalidan yang sangat tinggi. Penelitian dan Pengembangan (R\&D) model 4D menghasilkan e-modul matematika berbasis pendekatan RME yang valid dan layak untuk diuji cobakan di lapangan.

\section{DAFTAR PUSTAKA}

Apriansyah, M. F., \& Pujiastuti, H. (2020). Pengembangan Bahan Ajar Matematika berbasis Virtual Learning dengan Gnomio. Jurnal Pendidikan Matematika, 11(2), 179. https://doi.org/10.36709/jpm.v11i2.11921

Ardiyani, S. M. (2018). Realistic Mathematics Education in Cooperative. Journal on Mathematics Education, 9(2), 301-310. https://files.eric.ed.gov/fulltext/EJ1194281.pdf

Atikah, N., Karjiyati, V., \& Noperman, F. (2020). Pengaruh Model Realistic Mathematics Education Berbasis Etnomatematika Tabut terhadap Kemampuan Komunikasi Matematika Siswa Kelas IV SDN di Kota Bengkulu. Riset, Jurnal Dasar, Pendidikan, 3(1), 25-32.

Ediyanti, Gistituati, N., Fitria, Y., \& Zikri, A. (2020). Pengaruh Pendekatan Realistic Mathematics Education Terhadap Motivasi dan Hasil Belajar Materi Matematika SD. Jurnal Basicedu, 3(2), 524-532.

Fajri, Syarifuddin, H., \& Yerizon. (2020). Development of Realistic Mathematics Education ( RME ) Based Geometry Learning Design for 8th Grade Junior High School Students. International Journal of Progressive Sciences and Technologies (IJPSAT), 23(2), 417-420. http://ijpsat.ijsht-journals.org

Febriyanti, D. A., \& Ain, S. Q. (2021). Pengembangan Modul Matematika Berbasis Etnomatematika pada Materi Bangun Datar di Sekolah Dasar. Jurnal Basicedu, 5(3), 1409-1417.

Fernandes, M., \& Syarifudin, H. (2019). Pengembangan Perangkat Pembelajaran Pecahan Berbasis Model Penemuan Terbimbing. Elementary School Education Journal, 3(1), 93-103.

Fitria, Y., Helsa, Y., \& Hasanah, F. N. (2019). The learning tool for electric circuit and mathematics logic integration. Journal of Physics: Conference Series, 1321(3). https://doi.org/10.1088/1742-6596/1321/3/032108

Fitria, Yanti, Syarifuddin, H., \& MY, S. (2019). The Effect of Problem Based Learning and Motivation Models on Student Learning Outcomes in Mathematical Learning In Class Iv. IJEDS, 1(2), 79-86.

Fonda, A. (2018). The Developing Math Electronic Module With Scientific Approach Using Kvisoft Flipbook Maker Pro for XI Grade of Senior High School. Infinity, Journal of Mathematics Education, 7(2), 109122. https://doi.org/10.22460/infinity.v7i2.p109-122

Hendri, S., Handika, R., Kenedi, A. K., \& Ramadhani, D. (2021). Pengembangan Modul Digital Pembelajaran Matematika Berbasis Science, Technology, Engineering, Mathematic untuk Calon Guru Sekolah Dasar. Jurnal Basicedu, 5(4), 2395-2403.

Ilmi, R., Arnawa, I. M., Yerizon, \& Bakar, N. N. (2021). Development of an Android-Based for Math E-Module by using Adobe Flash Professional CS6 for Grade X Students of Senior High School. Journal of Physics: Conference Series, 1742(1). https://doi.org/10.1088/1742-6596/1742/1/012026

Kurani, R., \& Syarifuddin, H. (2020). Effectiveness of Mathematics Learning Tools Based on Guided Inquiry Model to Mathematical Communication Capabilities of Class VIII Students. Journal of Physics: Conference Series, 1554(1). https://doi.org/10.1088/1742-6596/1554/1/012006

Lachner, A., \& Nückles, M. (2016). Tell me why! Content knowledge predicts process-orientation of math 
6109 Validitas E-Modul Matematika Sekolah Dasar Berbasis Pendekatan Realistic Mathematics Education (RME) - Nur Atikah, Nurhizrah Gistituati, Hendra Syarifuddin, Yanti Fitria

DOI: https://doi.org/10.31004/basicedu.v5i6.1799

researchers' and math teachers' explanations. Instructional Science, 44(3), 221-242.

https://doi.org/10.1007/s11251-015-9365-6

Lasmiyati, \& Harta, I. (2014). Pengembangan Modul Pembelajaran untuk Meningkatkan Pemahaman Konsep dan Minat SMP Developing a Module to Improve Concept Understanding and Interest of Students of SMP. PYTHAGORAS : Jurnal Pendidikan Matematika, 9(2), 161-174.

Mentari, W. N., \& Syarifuddin, H. (2020). Improving student engagement by mathematics learning based on contextual teaching and learning. Journal of Physics: Conference Series, 1554(1). https://doi.org/10.1088/1742-6596/1554/1/012003

Oktaviara, R. A., \& Pahlevi, T. (2019). Pengembangan E-modul Berbantuan Kvisoft Flipbook Maker Berbasis Pendekatan Saintifik pada Materi Menerapkan Pengoperasian Aplikasi Pengolah Kata Kelas X OTKP 3 SMKN 2 Blitar Rhesta Ayu Oktaviara Triesninda Pahlevi. Jurnal Pendidikan Perkantoran, 07(03), 6065.

Sahidin, Desimarnis, Rusdinal, \& Gistituati, N. (2021). Efektivitas Penerapan Kebijakan E-Learning Masa Pandemi Covid-19 di Madrasah Aliyah. EDUKATIF: Jurnal Ilmu Pendidikan, 3(5), 2626-2637.

Samo, D. D. (2017). Kemampuan pemecahan masalah matematika mahasiswa tahun pertama dalam memecahkan masalah geometri konteks budaya. Jurnal Riset Pendidikan Matematika, 4(2), 141. https://doi.org/10.21831/jrpm.v4i2.13470

Sari, G., Gistituati, N., \& Syarifuddin, H. (2019). the Effect of Guided Discovery Learning Method Toward Students' Ability in Understanding Math Concept. International Journal of Educational Dynamics, 1(2), 54-60. http://ijeds.ppj.unp.ac.id/index.php/IJEDS

Syarifuddin, H. (2018). The Effect of Using Concept Maps in Elementary Linear Algebra Course on Students' Learning. IOP Conference Series: Materials Science and Engineering, 335(1). https://doi.org/10.1088/1757-899X/335/1/012107

Syaspasbandah, E. J., Syarifuddin, H., \& Jasrial, J. (2018). Pengembangan Perangkat Pembelajaran Matematika Berbasis Concept Attainment Model (CAM) untuk Peserta Didik Kelas VIII SMP. Journal of Medives : Journal of Mathematics Education IKIP Veteran Semarang, 2(1), 87. https://doi.org/10.31331/medives.v2i1.530

Tanujaya, B., Mumu, J., \& Margono, G. (2017). The Relationship between Higher Order Thinking Skills and Academic Performance of Student in Mathematics Instruction. International Education Studies, 10(11), 78. https://doi.org/10.5539/ies.v10n11p78

Widyatiningtyas, R., Kusumah, Y. S., Sumarmo, U., \& Sabandar, J. (2015). The impact of problem-based learning approach tosenior high school students' mathematics critical thinking ability. Journal on Mathematics Education, 6(2), 30-38. https://doi.org/10.22342/jme.6.2.2165.107-116

Yumiarti, D. S. (2020). Evaluation of Online Learning During the Covid-19 Pandemic on Universitas Negeri Padang. Edutec: Journal of Education and Technology, 3(2), 161-173.

Yuniati, S., Sari, A., Matematika, P. P., Tarbiyah, F., Hr, J., Km, S., Pekanbaru, T., \& Yuniati, S. (2018). Pengembangan Modul Matematika Terintegrasi Nilai-Nilai Keislaman Melalui Pendekatan Realistic Mathematics Education ( RME ) di Propinsi Riau. Jurnal Analisa, 4(1), 1-9. 